\title{
Komunikasi Persuasif pada Pendidikan Anak
}

\author{
Ike Junita Triwardhani
}

\begin{abstract}
There are two assumptions describing children learning process. First assumption theorized by France philosopher Jean Jacques Rousseau emphasized on the importance of children to return to nature. By learning in its natural space, Rousseau believed that children would achieve its peak performance in learning. The second assumption promoted by modern education experts such as Maria Montessori justified learning process more than learning space. For them, wherever children learn, one must attended the process of learning seriously. They believed that learning process would reach maximum impact if children learn in a state of playful mind. By nature, children love to play, and they learn through their play. Whatever theory picked up by educators, this article discussed the importance of persuasive communication on children learning process. Persuasive communication enabled children to develop creative mind which serve best to express themselves or to solve their problems.
\end{abstract}

Kata kunci: komunikasi persuasif, pendidikan anak, kreativitas

Ketika kita (orang dewasa) tengah berkomunikasi pada anak-anak (early childhood), seperti halnya proses komunikasi pada umumnya, adalah hal yang biasa. Namun, bagi anak, sebenarnya proses luar biasa tengah berlangsung di sini. Anak tengah mengalami proses transfer pengetahuan dari orang yang lebih dahulu mengetahui banyak pengalaman darinya. Anak tengah mengalami suatu proses belajar dari orang dewasa.

Proses belajar ini tentunya terjadi pada pribadi sang anak, bukan orang dewasanya. Bagaimana terpaan komunikasi ini membentuk sistem pengetahuan, sikap, dan perilaku berlangsung sesuai dengan proses yang khas pada anak-anak, yang bisa jadi sangat berbeda dengan proses pada orang dewasa. Maka stimuli ini akan menjadi efektif, jika disampaikan (dikomunikasikan) lewat bahasa yang sesuai dengan kekhasan anak itu. Dari sinilah ide ini dikembangkan yaitu mencoba menggali bagaimana komunikasi pada anak: bagaimana memahami anak dan selanjutnya bagaimana menggunakan bahasa-bahasa yang paling efektif dicerap dan mengena dalam benak anak tersebut.

Tulisan ini bukan membahas komunikasi pada anak di media. Ini lebih pada keseharian kita, bagaimana seharusnya kita (orang dewasa) memperlakukan anak-anak kita, terutama dalam hal berkomunikasi saat membimbingnya belajar. Tulisan ini juga diharapkan bisa memberikan sumbangan pada dunia pendidikan anak, terutama dalam metoda guru mengajarkan sesuatu kepada 
anak didiknya.

\section{Memahami Anak Belajar}

"Anak kecil ibarat bunga yang tengah berkembang di taman”. Sebuah kiasan indah yang diungkapkan oleh Friedrich Froebel kala memulai gagasannya tentang sekolah buat anak-anak usia dini, yang kemudian dinamakannya "Taman Kanakkanak (Kindergarten)" (Dryden \& Vos, 2000:105). Maka asumsi dasar yang kemudian melatari perkembangan taman kanak-kanak adalah asumsi bahwa "setiap anak adalah unik". Tiap anak berkembang sesuai dengan potensinya masingmasing. Dan prinsip dasar taman kanak-kanak adalah bukan menuntut anak untuk menjadi apa yang diinginkan oleh orang dewasa, tetapi anak menjadi dirinya sendiri "apa adanya (Tangyong, dkk., 1994:56).

Beberapa pakar pendidikan anak awal sangat menekankan pada karakteristik sifat alami dari anak itu. Jean Jaques Rousseau, Filsuf Perancis pada masa Renesans, menyarankan pendidikan anak yang "kembali ke alam" (a return to nature) dan pendekatan yang bersifat alamiah dalam pendidikan anak. Anak akan berkembang tanpa hambatan, karena pendidikan yang bersifat alamiah menghasilkan dan memacu berkembangnya kualitas semacam kebahagiaan, spontanitas, dan rasa ingin tahu.

Pendapat Rousseau diikuti oleh tokoh lain, Pestalozzi, yang menyatakan bahwa pendidikan sebaiknya mengikuti sifat-sifat bawaan anak (child's nature). Dasar dari metode ini merupakan perpaduan yang serasi antara nature dan pendidikan yang praktis. Yaitu, metode yang mengikuti nature atau dengan kata lain membimbing anak dengan perlahan, dan dengan usaha anak sendiri, bermula dari sense-impression menuju ide-ide yang abstrak. Sikapnya terhadap anak lebih bersifat belajar bersama anak daripada mengajar secara otoriter (Patmonodewo, 2000:58).

Anggapan kedua mengenai bagaimana anak belajar, adalah "setiap anak adalah 'pelajar' yang aktif'. Belajar bagi anak adalah sesuatu yang dikerjakannya. Anak-anak akan senang dan dia tengah belajar saat ia memperhatikan, mencium, meraba, dan membuat suara pada sesuatu yang ada di sekitar mereka. Proses belajar sebenarnya merupakan proses internalisasi, bukan melulu transfer pengetahuan. Dan pada dunia anak, proses internalisasi ini sangat efektif ketika anak ini menyenangi apa yang dipelajarinya.

Mengapa harus menyenangkan? Dengan suasana senang, sense of belonging anak terhadap apa yang tengah dipelajari akan tercipta. Dalam kondisi yang demikian, maka proses belajar akan mengalir dengan begitu saja, sinambung, berlanjut, sampai anak benar-benar menghayati dan menjiwai bukan sekedar mengetahui.

Para pemikir pendidikan anak-anak seperti Rousseau, Pestalozzi, Froebe, Montessori, juga Piaget, mengungkapkan perlunya proses dan suasana bermain dalam pendidikan anak untuk mendukung penciptaan suasana belajar yang menyenangkan. Bermain adalah naluri alamiah, fitrah anak-anak pada usianya. Bermain adalah sarana alamiah anak-anak untuk mengenali dirinya, melatih kemampuan indera dan motoriknya, membangun kehidupan sosial, dan membentuk kepribadian dirinya. Maka, sebaliknya, jika anakanak mengalami suasana tertekan, dan kehilangan kesempatan bermain secara alami, maka anak akan kehilangan kesempatan emas dalam mengembangkan potensi dan pribadinya.1).

Metode pengajaran yang menerapkan cara yang menyenangkan pada substansi pendidikan misalnya, dengan memberi materi yang menjadikan anak "merasa memiliki" dan merangsang munculnya kreativitas, misalnya dengan pendekatan partisipasi individu dan metode pengajaran yang sugestif yaitu dengan menerapkan metode komunikasi persuasif oleh guru, dan juga kedekatan antara guru dan anak. Kebersamaan dan toleransi adalah komponen vital dari iklim yang menyenangkan (Dryden \& Vos, 2000:305).

Ketika anak mengalami cara belajar yang menyenangkan, ada beberapa hal yang bisa terlihat sebagai hasil yang positif. Yang pertama adalah, anak sejak dini berhasil menemukan "minat belajar" pada dirinya. Minat belajar ini dipahami sebgai dorongan belajar yang tumbuh dari dalam dirinya. 
Minat belajar pada anak sering dilihat bahwa anak suka mengamati sekelilingnya, menanyakan banyak hal, dan mencoba hal-hal yang baru, sebagai wujud ekspresi rasa ingin tahu seorang anak kecil.

Belajar secara menyenangkan juga menjadi sarana kondusif untuk mendorong perkembangan kreativitas anak. Cara belajar yang menyenangkan akan menciptakan suasana yang menjamin terpeliharanya kebebasan psikologis. Pemerhati masalah anak dan remaja, Seto Mulyadi, memberi penekanan pada suasana bermain untuk membangun dan memelihara kebebasan psikologis itu, yang akan melatih dan memberikan kesempatan pada anak untuk menampilkan gagasan-gagasan baru secara lancar dan orisinal (Astono, 2001:4).

Anak usia prasekolah memiliki kreativitas alamiah yang tampak dari perilaku mereka yang sering bertanya, senang menjajaki lingkungan, tertarik untuk mencoba segala sesuatu, dan memiliki daya khayal yang tinggi. Elizabeth Hurlock menjelaskan, bahwa kreativitas anak ini sangat terkait dan diawali dengan proses bermain. Bermain memberikan kesempatan kepada anak untuk mengekspresikan dorongan-dorongan kreatifnya, juga kesempatan untuk merasakan objek-objek dan tantangan untuk menemukan sesuatu dengan caracara baru (Hurlock, 1999:10-11).

Bermain bagi anak bukan berarti suatu proses alamiah murni yang berlangsung tanpa arah. Seperti diungkapkan Froebel, tanpa arahan dan bimbingan, maka proses belajar akan menuju ke arah yang salah. Jika anak akan mempelajari sesuatu yang berarti dalam lingkungan bermain bebas, di mana anak boleh melakukan apa saja yang diinginkan, maka proses belajar tidak akan terjadi. Harus ada peran orang dewasa dalam proses bermain dan belajar anak, yaitu guru. Dalam konteks yang lebih umum, guru bisa dipahami sebagai orang dewasa yang bertanggung jawab dalam proses belajar anak -ia bisa berupa orang tua atau pengasuh- atau secara khusus adalah mereka yang mengajar anak di sekolah. Froebel menyatakan, bahwa guru bertanggung jawab dalam membimbing dan mengarahkan, dengan demikian anak menjadi kreatif(Patmonodewo, 2000:7).
Begitu pula dalam pengembangan kreativitas. Kreativitas tidak akan muncul pada anak, tanpa anak itu mengetahui sesuatu terlebih dahulu. Sebelum menemukan cara-cara yang baru dan orisinal, diperlukan pengetahuan yang diterima anak sebelumnya. Jadi, mereka mempunyai modal awal pengetahuan sehingga daya kreasinya pun tetap terarah walaupun tidak terkekang. Kreativitas tidak muncul dalam kehampaan. Semakin banyak pengetahuan yang dapat diperoleh anak, semakin baik dasar untuk mencapai hasil yang kreatif (Hurlock, 1999:11). Di sini guru atau orang tua bisa menjadi peran sentral yang mengantarkan pengetahuan kepada anak-anak.

Dalam interaksi antara guru dan anak tersebut, berlangsung proses komunikasi. Komunikasi pada anak akan berlangsung efektif, mengena pada benak anak, dan memberikan pengaruh signifikan dalam proses belajarnya, jika pesan disampaikan dengan memahami karakter anak itu, sehingga pesan-pesan itu dapat diterima anak sebagai sesuatu hal yang menyenangkan.

\section{Pendekatan Komunikasi Persuasif dalam Pendidikan Anak}

Dalam ilmu komunikasi, banyak pendekatan yang bisa digunakan untuk melihat komunikasi dalam dunia pendidikan. Dalam hal ini, penulis memilih pendekatan komunikasi persuasif untuk menjelaskan komunikasi kepada anak. Persuasi sendiri merupakan usaha pengubahan sikap individu dengan memasukkan ide, pikiran, pendapat, dan bahkan fakta baru lewat pesanpesan komunikatif (Roekomy, 1992). Pendekatan ini dipilih karena dapat menjelaskan bagaimana komunikator (guru) harus memahami betul karakter komunikan (anak) dalam proses komunikasi.

Ada beberapa alasan penggunaan pendekatan komunikasi persuasif dalam melihat komunikasi pada pendidikan anak iini ${ }^{111}$

Prinsip-prinsip Komunikasi Persuasif ini disarikan dari Pedoman yang dikeluarkan oleh Departeman Sosial dan UNDP tentang Penyelesaian Masalah Anak Jalanan, 1997.

(1) Bersikap sejajar 
Komunikasi persuasif mensyaratkan adanya kesejajaran antara komunikan dan komunikator; komunikator tidak bersifat menggurui. Di sini, tercipta suasana kebersamaan; komunikator mencoba mendalami komunikan; dan komunikan menganggap komunikator sebagai teman; dan pesan bisa diterima akibat proses kedekatan yang terjadi.

Dalam konteks komunikasi pada pendidikan anak, sikap kesejajaran ini ditunjukkan ketika guru tidak menganggap dirinya lebih tahu segalanya bagi anak, sehingga cenderung memaksa anak untuk mengikuti kemauan guru. Ketika ia menempatkan diri sebagai seorang teman bercerita, dan dia berusaha mendalami anak, maka sang anak akan merasa dekat dengan guru, sehingga pesan yang disampaikan guru akan dilaksanakan oleh anak sebagai dorongan yang muncul dari dalam.

(2) Memperbanyak diskusi. Komunikasi persuasif banyak melibatkan komunikan untuk menyampaikan pendapatnya dalam proses komunikasi. Sangat mungkin, dalam komunikasi persuasif, pesan yang diterima merupakan hal yang sebenarnya sudah diketahui oleh komunikan; komunikator hanya memberikan penegasan atau penjalasan lebih kuat terhadap apa yang sudah dipahami komunikan.

Dalam konteks pendidikan anak, misalnya, ketika guru bercerita, ia merasa perlu untuk memberi kesempatan anak untuk ikut memberi komentar terhadap apa yang ia ceritakan. Dengan demikian terbuka kesempatan bagi guru untuk menyampaikan pesan, misalnya pesan moral dan nilai-nilai, dengan menggunakan kerangka pemahaman yang sudah ada pada anak tersebut (misalnya yang sudah terbentuk dari keluarga). Suasana diskusi, dalam konteks anak-anak akan lebih berupa kegiatan mengobrol atau bercerita bersama, lebih memungkinkan proses transfer pengalaman sesama anak. Dan, anak akan lebih mudah memahami dan mendalami pesan ini, karena pesan ini bukan sesuatu yang asing buat mereka.

(3) Mengarahkan secara halus. Komunikasi persuasif tidak bersifat memaksa; perubahan sikap atau perilaku berasal dari dorongan pribadi. Dangan demikian komunikasi persuasif lebih menciptakan sikap dan perilaku yang konsisten. Cara-cara kasar cenderung membuat komunikan menjalankan keinginan komunikator karena rasa takut, bukan atas kesadaran sendiri.

Dalam konteks pendidikan anak, mengarahkan secara halus akan menghindarkan anak dari rasa takut dan keterpaksaan ketika anak melakukan sesuatu yang sebenarnya merupakan perintah dari guru. Suatu cara-cara halus yang menyentuh emosi dan afeksi anak akan membuat anak merasa memiliki dan menyenangi tindakan yang harus dilakukan itu.

(4) Mendampingi. Tujuan komunikasi persuasif adalah perubahan sikap dari komunikan, sehingga komunikator perlu terus bertanggungjawab, mengawal atau mendampingi komunikan hingga sikapnya berubah sesuai dengan yang dikehendaki. Dalam konteks pendidikan anak, komunikasi tidak akan efektifjika guru hanya memberikan instruksi, dan kemudian membiarkan anak memahami pesan tersebut tanpa arahan. Ketika sang anak tengah menjalankan apa yang diinginkan guru, maka pendampingan akan membuat anak merasa aman karena ia merasa ada yang siap memberi pertolongan jika ia membutuhkan.

(5) Mendengarkan keluh kesah. Komunikasi persuasifmengakomodasi hal-hal yang di luar konteks komunikasi, namun berpengaruh pada kondisi emosional komunikan. Keluh kesah komunikan perlu menjadi pertimbangan, karena keluh kesah ini bisa menjadi penghambat ketika komunikan hendak menjalankan apa yang dimaui komunikator.

Dalam konteks pendidikan anak, hal ini terlihat ketika guru harus sabar dlam melayani permintaan anak-anak yang sebenarnya tidak terkait dengan apa yang tengah diajarkan. 
Suatu pengekangan atau pembatasan terhadap keluh kesah akan mengurangi rasa kepemilikan terhadap apa yang disampaikan

Kekuatan dari komunikasi persuasif sangatlah penting dalam belajar, karena keberhasilan komunikasi ini ditentukan oleh tindakan atau sikap komunikan yang tumbuh akibat dorongan dari dalam. Dalam konteks pendidikan, komunikasi secara persuasif yang dapat membentuk motivasi belajar. Seorang anak dapat melakukan sesuatu dengan baik jika berpikir bahwa dia mampu untuk melakukannya.

\section{Penutup}

Ada beberapa hal yang bisa disimpulkan dari makalah ini. Anak-anak adalah dunia yang khas. Mereka mempunyai potensi yang khas dalam masing-masing pribadi. Apa yang menjadi imajinasi, cara berpikir dan bahasa anak-anak adalah bersifat natural dan bukan melulu miniatur orang dewasa. Anak tumbuh dan berkembang, sehingga anak-anak perlu belajar. Proses belajar itu menjadi efektif dan lebih membentuk pribadi/ karaketer anak tersebut, jika anak menyenangi apa yang dipelajarinya.

Guru berperan dalam pengembangan kreativitas anak (murid taman kanak-kanak), yang tertuang dalam metoda/ cara-cara mengajar anak. Metoda komunikasi yang diterapkan dalam membangun kreativitas itu adalah metoda komunikasi persuasif. Banyak cara yang bisa dilakukan guru dalam pengajaran dengan metode komunikasi persuasif untuk mengembangkan kreativitas anak.

Namun, dalam kejadian sehari-hari, kita sering menemukan hal sebaliknya, banyak tindakan guru, meskipun maksudnya baik, seperti mengajarkan kedisiplinan atau penerapan norma-norma, namun dengan cara berkomunikasi yang kurang tepat, justru menjadikan murid merasa tidak menyenangi apa yang diajarkan dan mengekang kreativitas. Metode deterministik dalam cara mengajarnya menjadikan anak merasa terkekang dan tidak nyaman, bahkan menjadi takut dalam belajar. Dan, dari sini, mulailah terjadi proses pengekangan terhadap potensi pribadi anak.
Dengan pendekatan komunikasi persuasif, ada beberapa hal yang dapat dilakukan guru untuk mengembangkan kreativitas murid. Guru seharusnya mampu membangun minat belajar pada anak, dan membuatnya selalu senang belajar. Sikap guru terhadap anak lebih bersifat belajar bersama anak, daripada mengajar secara otoriter yang justru akan memasung kreativitas anak. Untuk menjadi pembimbing dan pengarah yang baik terlebih dahulu guru harus memahami anak.

Guru dapat berperan aktif menciptakan suasana bermain melalui sikap menghargai dan menghormati keberadaan anak sebagai individu, menerima anak sebagaimana adanya, memberikan kebebasan pada anak, dan menjauhi sikap otoriter dalam memupuk bakat dan minat anak untuk berprestasi dan berkreasi secara aktual.

Proses ini juga ditambah dengan faktor-faktor umpan balik positif dan rangsangan dari lingkungan. Seorang anak memiliki bakat, kemampuan dan kualitas yang masih bersifat potensial, belum teraktualisasi pada dirinya. Untuk itu, peran orang tua dan guru, sebagai fasilitator untuk membantu mewujudkannya, sangat diperlukan.

Anak harus diajarkan untuk berani mencoba kemampuan melihat kemungkinan, keyakinan memilih strategi, dan kesempatan untuk melaksanakan strategi pilihannya. Pilihan-pilihan terkadang harus diberikan untuk merangsang anak, karena kreativitas memerlukan rangsangan dari luar untuk berkembang.

Kreativitas tidak muncul seketika. Pengembangan kreativitas harus dimungkinkan sejak masa dini. Anak-anak di Taman Kanak-kanak hendaknya bebas mengekspresikan perasaan dan pikirannya melalui berbagai benda. Cara anak mengekspresikan diri jauh lebih penting dari apa yang diekspresikan. Ekspresi diri dapat menumbuhkan rasa puas dan menjadikan mereka percaya diri serta membantu mereka menumbuhkan konsep diri yang positif

Mengingat kreativitas lebih menekankan pada ekspresi yang dilakukan anak, maka lebih baik anak dibiarkan memiliki bentuk ekspresi sendiri daripada diarahkan pada bentuk tertentu yang hanya 
meniru, misalnya dalam menggambar gunung atau menghafal puisi. Dengan meniru, anak tidak diberi kesempatan untuk membuat sesuatu yang baru yang mengandung ciri-ciri kreativitas.

Untuk memfasilitasi perkembangan anak, guru memegang peranan yang penting. Peran ideal yang seharusnya diterapkan: membantu anak agar memahami alasan tentang diterapkannya aturan, membantu anak untuk memahami dan membiasakan mereka untuk bekerjasama, saling menghormati dan memberikan informasi yang sebanyak-banyaknya kepada anak tentang hal-hal yang dibutuhkan anak. Ketika merancang pendidikan anak, seharusnya dimulai dengan perbincangan apa yang paling diperlukan anak-anak. Merancang sebuah program dengan penumbuhan rasa percaya diri, ketrampilan belajar, kemampuan berkomunikasi dalam suatu lingkungan yang menyenangkan.

Ketika seorang anak benar-benar merasakan kehadiran guru yang melebihi arti sekadar kehadiran fisik saja, maka rasa percaya kepada gurunya semakin tinggi. Kepercayaan ini akan mendorong anak untuk lebih membuka diri kepada gurunya dan mendorong meningkatnya intensitas komunikasi yang terjalin di antara mereka. Untuk menumbuhkan motivasi dan mempertahankan minat, ketika berinteraksi dengan siswa harus tetap memelihara pandangan positifmengenai diri mereka dan apa yang dapat mereka capai.

Guru harus menjaga agar murid tetap terlibat dalam komunitas belajar dan menjaga agar tingkat minat tetap tinggi. Guru harus terus memotivasi murid agar mereka ingin belajar dengan menciptakan suasana yang menyenangkan dan menarik diantaranya dengan berkomunikasi yang mengena pada diri anak. Komunikasi yang efektif sangat diperlukan dalam mendidik anak

Saat ini kita bisa menemukan guru-guru yang secara naluriah dan didorong kecintaannya terhadap anak, menerapkan cara belajar yang menyenangkan yang disukai anak. Ia mampu membangkitkan minat, kreativitas, dan kecintaan anak terhadap apa yang dipelajarinya. Beberapa hal yang menyebabkan anak senang dan membangkitkan minat belajar murid, dirumuskan penulis sebagai beriikut:
(1) penggunaan bahasa yang dimengerti dan sesuai dengan dunia anak.

(2) Memahami apa yang dirasakan oleh anak (empati).

(3) Pendampingan terhadap murid dalam mengaplikasikan materi yang disampaikan.

(4) Bentuk pujian dan dorongan yang bisa meningkatkan kesenangan murid dalam belajar.

(5) Pemberian materi cenderung mendukung kebebasan berpikir dan berkreasi pada murid. Kata kunci dari bagaimana untuk memahami dan berkomunikasi dengan baik kepada anak adalah "empati." Dengan empati apa yang kita sampaikan, diharapkan mengena dan sesuai dengan apa yang sebenarnya diinginkan dan dibutuhkan seorang anak. Empati dimaksudkan dengan mampu menerima sudut pandang orang lain, memiliki sikap empati atau kepekaan terhadap perasaan anak dan mampu mendengarkan anak.

\section{Catatan Akhir}

Sebuah fakta penelitian menyebutkan masa pra sekolah (anak usia 3-6 tahun) sebenarnya merupakan masamasa terbaik bagi perkembangan anak. Otak seorang anak hingga usia enam atau tujuh tahun adalah seperti spons, menyerap berbagai fakta, sifat-sifat fisik, dan menyusun bahasa dengan cara yang menyenangkan (De Porter dan Hernacki,1999).

\section{Daftar Pustaka}

Applbaum, Ronald L. \& Anatol, Karl W.E. 1974. Strategies For Communication. Columbus, Ohio: Charles E. Merrill Publishing Company \& A Beil \& Howell Company.

Azwar, Saifuddin. 2000. Sikap Manusia: Teori dan Pengukurannya. Yogyakarta: Pustaka Pelajar.

DePorter, Bobbi \& Mike Hernacki. 1999. Quantum Learning: Membiasakan Melajar Nyaman dan Menyenangkan. Bandung: Kaifa.

DePorter, Bobbi, Mark Reardon \& Sarah Singer Nourie. 2000. Quantum Teaching: Mempraktikkan Quantum Learning di Ruang-ruang Kelas. Bandung: Kaifa. 
Dryden, Gordon \& Jeannette Vos. 2000. Revolusi Cara Belajar: Keajaiban Pikiran. Bandung: Kaifa.

Dryden, Gordon \& Vos, Jeannette. 2000. Revolusi Cara Belajar: Sekolah Masa Depan Bandung: Kaifa.

Hurlock, Elizabeth. 1999. Perkembangan Anak. Jilid 1 \& 2. Alih Bahasa: dr. Med. Meitasari Tjandrasa. Jakarta: Erlangga.

Infante, Dominic A., Andrew S. Rancer, Deanna F Womack. 1990. Building Communication Theory. IIIinois: Waveland Press,Inc.

Larson, Charles U. Persuasion: Reception and Responsibility.

Munandar, Utami. 1999. Pengembangan Kreativitas Anak Berbakat. Jakarta: Rineka Cipta.

Patmonodewo, Soemiarti. 2000. Pendidikan Anak Prasekolah. Jakarta: Rineka Cipta.
Purwanto, M.Ngalim. 2000. Psikologi Pendidikan. Bandung: Remaja Rosdakarya.

Rahmawati, Shinta(Editor). 2001. "Mencetak Anak Cerdas dan Kreatif”. Kumpulan Artikel Kompas. Jakarta: Penerbit Buku Kompas.

Rakhmat, Jalaluddin. 1992. Psikologi Komunikasi. Bandung: Remaja Rosdakarya.

Roekomy. 1992. Dasar-dasar Persuasif. Bandung: Citra Aditya Bakti.

Tan, Alexis, 1981. Mass Communication: Theories and Research. Columbus: Grid Publishing Inc. Indianola Avenue, United States.

Tangyong, Agus F, dkk. 1994. Pengembangan Anak Usia Taman Kanak-kanak. Jakarta: Grasindo.

Yusuf, Syamsu. 2000. Psikologi Perkembangan Anak dan Remaja. Bandung: Remaja Rosdakarya. 
